\title{
Juvenile idiopathic arthritis with involvement of the temporomandibular joint: the role of image examinations
}

\author{
Artrite idiopática juvenil com envolvimento da articulação \\ temporomandibular: o papel dos exames por imagens entre \\ os recursos de diagnóstico
}

\begin{abstract}
Purpose: Juvenile idiopathic arthritis (JIA) has unknown etiology, and the involvement of the temporomandibular joint (TMJ) is rare in the early phase of the disease. The present article describes the use of computed tomography (CT) and magnetic resonance (MRI) images for the diagnosis of affected TMJ in JIA.

Case description: A 12-year-old, female, Caucasian patient, with systemic rheumathoid arthritis and involvement of multiple joints was referred to the Imaging Center for TMJ assessment. The patient reported TMJ pain and limited opening of the mouth. The helical CT examination of the TMJ region showed asymmetric mandibular condyles, erosion of the right condyle and osteophyte-like formation. The MRI examination showed erosion of the right mandibular condyle, osteophytes, displacement without reduction and disruption of the articular disc.

Conclusion: The disorders of the TMJ as a consequence of JIA must be carefully assessed by modern imaging methods such as CT and MRI. CT is very useful for the evaluation of discrete bone changes, which are not identified by conventional radiographs in the early phase of JIA. MRI allows the evaluation of soft tissues, the identification of acute articular inflammation and the differentiation between pannus and synovial hypertrophy.
\end{abstract}

Key words: Juvenile idiopathic arthritis; temporomandibular joint; computed tomography; magnetic resonance imaging

\section{Resumo}

Objetivo: A artrite idiopática juvenil (AIJ) tem etiologia desconhecida e o envolvimento da articulação temporomandibular (ATM) é raro no estágio inicial da doença. Este artigo descreve o uso de imagens de tomografia computadorizada (TC) e de ressonância magnética (RM) para o diagnóstico de ATM afetada pela AlJ.

Descrição do caso: Uma paciente de 12 anos de idade, leucoderma, portadora de AlJ com envolvimento de múltiplas articulações foi encaminhada ao Centro de Imaginologia para avaliação das ATMs. A paciente relatou dor na ATM e limitação de abertura bucal. O exame com TC helicoidal da região da ATM com reconstruções a $1 \mathrm{~mm}$ mostrou assimetria entre os côndilos mandibulares, erosão do côndilo direito e formação osteofítica. $\bigcirc$ exame de RM mostrou erosão do côndilo mandibular direito, osteófito, deslocamento sem redução e ruptura do disco articular.

Conclusão: As desordens de ATM devido à AlJ devem ser cuidadosamente examinadas por modernas técnicas de imagem. A TC é muito útil para a deteç̧ão e avaliação de estruturas ósseas da ATM e permite o exame de alterações ósseas discretas, que não seriam identificadas por radiografias convencionais nas fases iniciais de AIJ. A RM permite a avaliação de tecidos moles, identificação de inflamação articular aguda e diferenciação entre hipertrofia sinovial e do pannus.

Palavras-chave: Artrite idiopática juvenil; articulação temporomandibular; tomografia computadorizada; ressonância magnética

\author{
Karina Ivette Sánchez Effio “ \\ Luciana Maria Paes da Silva \\ Ramos Fernandes ${ }^{b}$ \\ Marcelo Eduardo Pereira Dutrac \\ Marcelo Marcucci d \\ Jefferson Xavier de Oliveira ${ }^{\text {e }}$
}

\begin{abstract}
- Private practice, Lima, Peru
b Graduate Program in Stomatology, Bauru Dental School, University of São Paulo, Bauru, SP, Brazil

c University Santa Cecília, Santos, SP, Brazil

d Department of Stomatology and Oral-Maxillofacial Surgery, Heliópolis Hospital, São Paulo, SP, Brazil

e Discipline of Radiology, Dental School, University of São Paulo, São Paulo, SP, Brazil
\end{abstract}




\section{Introduction}

Juvenile idiopathic arthritis (JIA) is a chronic pediatric connective tissue disease that affects joints, influences function, and can lead to growth disturbances or disability (1). To be considered JIA, the disease should manifest before the 16 years of age, affect one or more joints and persist longer than 6 weeks $(1,3,4)$. JIA affects more frequently female than male patients (1-5).

JIA represents a heterogeneous group of chronic inflammatory arthritis, and no specific term is universally accepted to classify the disease. The most recent terminology was presented in the Classification Taskforce of the Pediatric Standing Committee of the International League of Associations for Rheumatology (ILAR), proposed in 1994, in Santiago, Chile, and revised in 1997, in Durban, South Africa (6). ILAR aimed to create a classification model to divide children with chronic arthritis into homogeneous subtypes, providing a better understanding of the main causes of the disease and making easier the communication between researchers and professionals around the world. The ILAR criteria were developed to replace the terminology proposed by the American College of Rheumatology (ACR)'s ("juvenile rheumathoid arthritis") and the European League Against Rheumatism (EULAR) ("juvenile chronic arthritis"). These models were changed by ILAR to the new term universally accepted "juvenile idiopathic arthritis" (JIA) $(3,4)$. The classifications of each society are shown in Table 1.

The etiology of JIA is still unknown. The possible associated factors are infections, physical trauma, immunological disturbances, genetic predisposition, psychological factors and family influence. Heredity is considered an important risk factor (7), and infections may precipitate the disease $(3,4)$.

The involvement of temporomandibular joint (TMJ) in JIA was recognized in 1897 (8). Although the rate of involvement of TMJ in JIA has not been determined yet, studies with patients with rheumatoid arthritis (RA) indicate that almost 43 to $70 \%$ of the cases involve this joint. Unlikely other synovial joints, the TMJ mandibular growth plate is located just beneath the fibrocartilage of the mandibular condyle, which is particularly vulnerable to inflammatory damage.
The destruction of fibrocartilage induced by arthritis can lead to significant limitation of mandibular growth and development $(2,6,8,9)$.

Twenty-five percent of the patients with JIA have alterations in TMJ. These patients present destruction of articular structures, which can lead to typical facial expressions (10), such as the "bird face" (6). This can result in facial deformity such as asymmetry, micro and retrognathia (9), hypoplasy of the mandibular condyle, and consequent class II malocclusion, anterior open bite (4) and increased overjet (10). The morphologic facial feature is usually associated with the destruction of the mandibular condyle (11). The ultimate and dramatic consequence of the joint destruction is TMJ ankylosis and biting limitation (9).

Although TMJ involvement in children with JIA is not uncommon, it rarely occurs at the early phase of the disease. The most reported symptoms are pain during activity and at rest, restriction of the maximal voluntary mouth opening, morning stiffness, TMJ crepitation (9) and mandible deviation (11), which are evidences of the internal TMJ degeneration. However, the clinical examination alone is not reliable for detecting TMJ degenerative processes (5). The image examinations such as computed tomography (CT) and magnetic resonance imaging (MRI) are important to assess the condition of bones and soft structures of the TMJ.

TMJ can be uni- or bilaterally affected, in several stages of the disease, with associated pain or with complete absence of symptoms. This has contributed to the difficulties of clinical identification of JIA for many years. The present article describes the computed tomography (CT) and the magnetic resonance (MRI) images of a 12-year-old patient who presented JIA with TMJ involvement.

\section{Description of the case}

A 12-year-old, female, Caucasian patient, with systemic RA and involvement of multiple joints was referred to the Imaging Center in order to have the TMJ structures assessed by advanced image methods. The patient reported TMJ pain and limited opening of the mouth. Firstly, the helical CT examination of the TMJ region was performed, with the scanner HiSpeed CT/i (General Electric, USA), at $120 \mathrm{kV}, 200 \mathrm{~mA}$, slice thickness of $1.0 \mathrm{~mm}$, with overlapping reconstructions every $1.0 \mathrm{~mm}$ and bone algorithm.

Table 1. Comparison of the ILAR, EULAR and ACR criteria for classification of JIA.

\begin{tabular}{lll}
\hline \multicolumn{1}{c}{$\begin{array}{c}\text { ILAR } \\
\text { JIA }\end{array}$} & \multicolumn{1}{c}{$\begin{array}{c}\text { EULAR } \\
\text { (Juvenile Chronic Arthritis) }\end{array}$} & $\begin{array}{c}\text { ACR } \\
\text { JCA }\end{array}$ \\
\hline Systemic arthritis & Systemic arthritis & Systemic arthritis \\
Polyarthritis RF-positive & Polyarticular arthritis & Pauciarticular arthritis \\
Polyarthritis RF-negative & JCA, RF-positive & Polyarticular arthritis \\
Oligoarthritis (subtypes persistent and extended) & Pauciarticular Arthritis & \\
Enthesitis related arthritis & Juvenile ankylosing spondylitis & \\
Psoriatic arthritis & & \\
\hline
\end{tabular}

${ }^{*}$ ACR = American College of Rheumatology; EULAR = European League Against Rheumatism; ILAR = International League of Associations for Rheumatology; $\mathrm{RF}=$ rheumatoid factor (6). 
Figure 1 shows a coronal section in which it is possible to observe asymmetry between both mandibular condyles (MCs) and erosion of the anterior aspect of the right condyle. The sagittal section (Fig. 2) shows the loss of the right MC cortical wall and associated osteophyte-like formation.

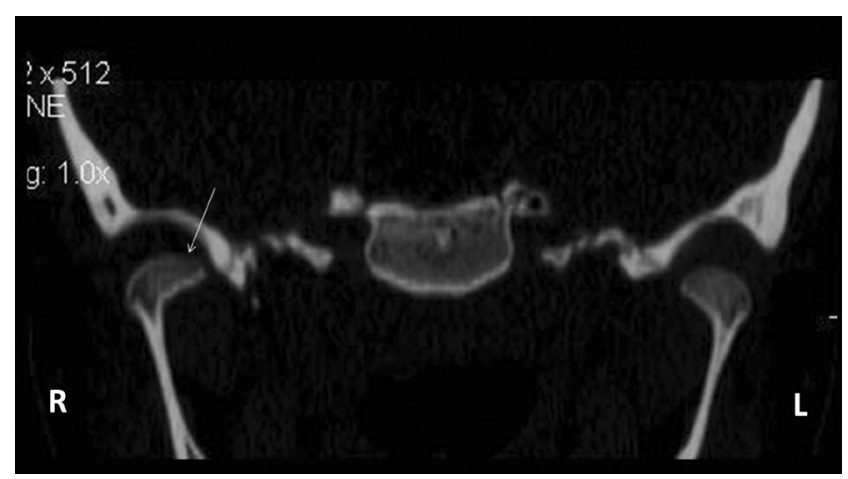

Fig. 1. CT image: coronal section of the TMJ region, bone algorithm, in which it is possible to observe alteration of the cortical of right mandibular condyle.

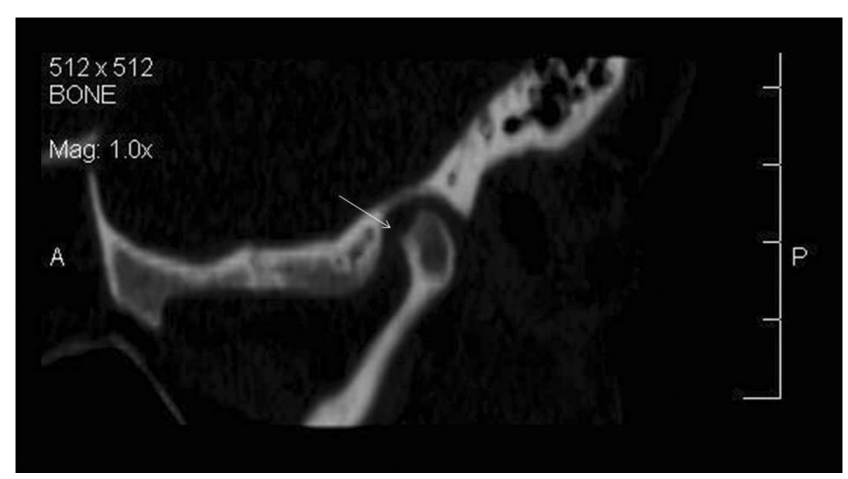

Fig. 2. CT image: sagittal section of the right $M C$, bone algorithm, in which it is possible to see loss of cortical limit of the anterior-upper mandibular condyle and suggestive erosion area with related osteophyte-like formation.

The patient also underwent MRI examination using a $1.5 \mathrm{~T}$ Signa (General Electric, USA) scanner with bilateral surface coils, T1-weighted images, slice thickness and gap of $3.0 \mathrm{~mm}$. Figure 3 is a T1-weighted image in maximum mouth opening position, in sagittal view, in which the arrow indicates bony projection (osteophyte). It is also possible to see displacement without reduction and disruption of the articular disc. Figure 4 is an inverted T1-weighted image, in maximum mouth opening position, in which erosive process of right $\mathrm{MC}$ and derived anatomic change of the articular disc are shown.

\section{Discussion}

JIA can affect any joint of the body and the involvement of TMJ is uncommon at the early phase of the disease. This

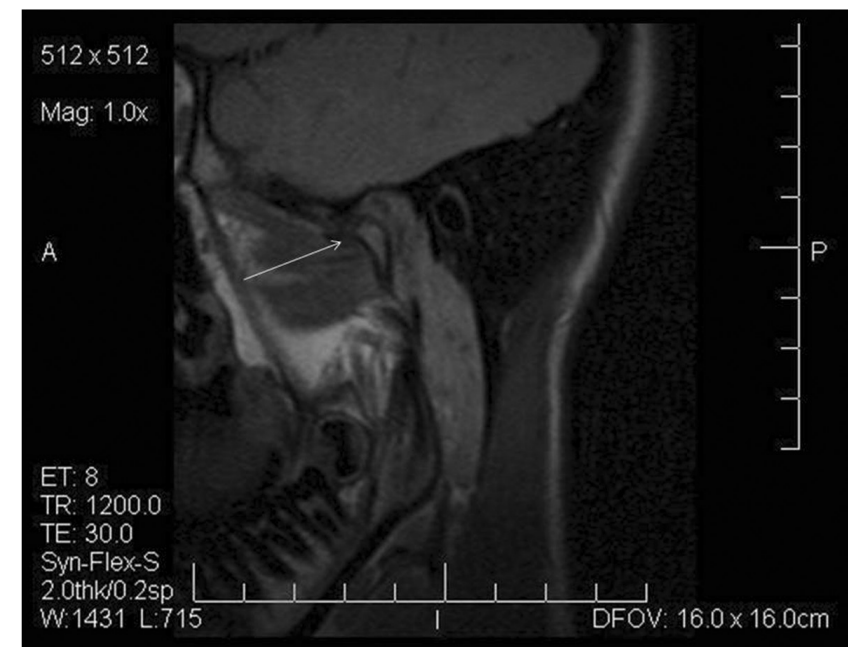

Fig. 3. T1-weighted MRI: sagittal section of the right side in opened-mouth position, showing erosive process, and displacement without reduction and disruption of the articular disc.

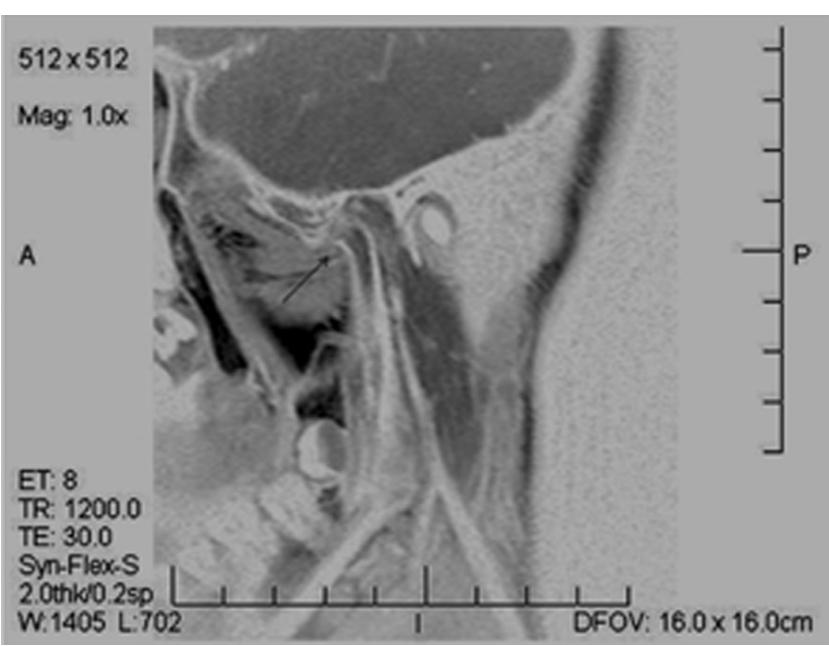

Fig. 4. T1-weighted inverted MRI: sagittal section of the right side in opened-mouth position, showing erosive process of the right mandibular condyle.

involvement is reported in $63 \%$ of the patients with JIA and the disease affects TMJ differently from the other joints (12). The high frequency of TMJ involvement has often been reported in children with JIA, and several papers stated that the TMJ involvement can lead to dysplastic mandibular growth, micrognathia in $30 \%$ of the cases (8), malocclusion in $69 \%$ and oral function disturbances (13). TMJ represents a challenge for the JIA-related diagnosis and treatment since its anatomy and physiology are complex, which requires the association of clinic examination and imaging assessment, and sometimes laboratory analysis (14). Conventional radiographs, CT, MRI and ultrasound are successfully used for the detection of MC resorption secondary to TMJ arthritis (15). In the present case, the professional did not require an ultrasound examination of the patient. 
$\mathrm{CT}$ and MRI represent the current gold standards for the assessment of bones and soft structures, respectively (14). Even though conventional radiograph is still considered as an important tool for the detection of degenerative processes of the TMJ in patients with JIA, CT can provide further information beyond the two-dimensional images obtained with radiographic methods. The three-dimensional images offered by $\mathrm{CT}$ can contribute to clarify the relation between signs and symptoms of TMJ dysfunction and skeletal abnormalities (5). Furthermore, CT slices help to detect the bony destruction not seen in conventional radiographic methods. This fact can lead to the diagnosis of TMJ disorder, since CT reveals early pathological changes of the joint, such as limited joint space and MC erosion (7). In the present case, $\mathrm{CT}$ allowed the observation of loss in the anterior aspect of right $\mathrm{MC}$ and presence of osteophyte-like formation, which are consequences of TMJ alteration secondary to JIA.

MRI allows the assessment of soft structures of the joint in detail and of pathological processes secondary to TMJ involvement in JIA. In the present case, this imaging tool was also used and allowed the observation of erosive process of the affected MC, displacement and disruption of the articular disc.

Hu et al. (5) reported bony abnormalities of TMJ in children with JIA by using CT; almost $2 / 3$ of the children presented variable stages of MC degeneration. Kitai et al. (13) used CT or MRI of the TMJ and reported similar findings.
Conventional radiographs, CT and MRI were able to show that the articular eminence had become remarkably flat and that the depth of the glenoid fossa had been reduced in patients with JIA.

Scolozzi et al. (9) reported a case in which CT and MRI were used to reach the final diagnosis of JIA, with typical findings such as synovial pannus, abundant intra-articular effusion (as shown in MRI) and multiple articular bony erosions (as shown in both the CT and MRI). In a review on affected TMJ in JIA, Arabshahi e Cron (15) stated that CT allows the observation of the $\mathrm{MC}$ and its erosive processes. However, this image method would not be reliable for the detection of alterations in soft tissues, which can indicate acute TMJ disorder. For this reason, MRI is mandatory for the assessment of soft tissues of TMJ affected by JIA.

\section{Conclusions}

The disorders of the TMJ as a consequence of JIA must be carefully assessed by modern imaging methods such as CT and MRI. CT is very useful for the detection and evaluation of bony alterations of TMJ and allows the assessment of discrete bone changes, which are not identified by conventional radiographs in the early phase of JIA. MRI allows the evaluation of soft tissues, the identification of acute articular inflammation and the differentiation between pannus and synovial hypertrophy.

\section{References}

1. Sidiropoulou-Chatzigianni S, Papadopoulos MA, Kolokithas G. Dentoskeletal morphology in children with juvenile idiopathic arthritis compared with healthy children. J Orthod 2001 ;28:53-8.

2. Kjellberg H. Craniofacial growth in juvenile chronic arthritis. Acta Odontol Scand 1998;56:360-5

3. Kiellberg H, Fasth A, Kiliaridis S, Wenneberg B, Thilander B. Craniofacial structure in children with juvenile chronic arthritis (JCA) compared with healthy children with ideal or postnormal occlusion. Am J Orthod DentoFac Orthop 1995; 107:67-78.

4. Bakke M, Zak M, Jensen BL, Pedersen FK, Kreiborg S. Orofacial pain, jaw function, and temporomandibular disorders in women with a history of juvenile chronic arthritis or persistent juvenile chronic arthritis. Oral Surg Oral Med Oral Pathol Oral Radiol Endod $2001 ; 92: 406-14$

5. Hu YS, Schneiderman ED, Harper RP. The temporomandibular joint in juvenile rheumatoid arthritis: Part II. Relationship between computed tomographic and clinical findings. Pediatr Dent 1996; 18:312-9

6. Twilt M, Mobers SM, Arends LR, ten Cate R, van Suijlekom-Smit L. Temporomandibular involvement in juvenile idiopathic arthritis. J Rheumatol 2004;31:1418-22.

7. Hu YS, Schneiderman ED. The temporomandibular joint in juvenile rheumatoid arthritis: I. Computed tomographic findings. Pediatr Dent 1995; 17:46-53.

8. Arabshahi B, Dewitt EM, Cahill AM, Kaye RD, Baskin KM, Towbin RB, Cron RQ. Utility of corticosteroid injection for temporomandibular arthritis in children with juvenile idiopathic arthritis. Arthritis Rheum 2005;52:3563-9

9. Scolozzi P, Bosson G, Jaques B. Severe isolated temporomandibular joint involvement in juvenile idiopathic arthritis. J Oral Maxillofac Surg 2005;63:1368-71.

10. Pedersen TK. Clinical aspects of orthodontic treatment for children with juvenile chronic arthritis. Acta Odontol Scand 1998;56:366-8.

11. Twilt M, van der Giesen E, Mobers SM, ten Cate R, van SuijlekomSmit LW. Abrupt condylar destruction of the mandibula in juvenile idiopathic arthritis. Ann Rheum Dis 2003;62:366-7.

12. Pedersen TK, Gronhoj J, Melsen B, Herlin T. Condylar condition and mandibular growth during early functional treatment of children with juvenile chronic arthritis. Eur J Orthod 1995; 17:385-94.

13. Kitai N, Kreiborg S, Murakami S, Bakke M, Moller E, Darvann TA, Takada K. A three-dimensional method of visualizing the temporomandibular joint based on magnetic resonance imaging in a case of juvenile chronic arthritis. Int J Paediatr Dent 2002;12: 109-15.

14. Engelmann LM, Oliveira MG, Oliveira HW. Análise da articulaçäo temporomandibular de pacientes adultos com artrite reumatóide por tomografia computadorizada de alta resolução. RFO UPF $2001 ; 6: 59-66$.

15. Arabshahi $B$, Cron RQ. Temporomandibular joint arthritis in juvenile idiopathic arthritis: the forgotten joint. Curr Opin Rheumatol 2006; 18:490-5. 